\author{
Tõnno Jonuks, Ragnar Saage
}

\title{
AN ANTIQUARIAN GIFT - \\ A COLLECTION OF PERM \\ ANIMAL-STYLE PLAQUETTES \\ IN THE ESTONIAN HISTORY MUSEUM
}

\section{DISCOVERY STORY}

In 1873, a short notice appeared in the Revalsche Zeitung (no. 256, 02.11.1873), in which the Provincial Museum, currently the Estonian History Museum, introduced the new museum exhibits that had arrived in its collection. Among other new objects in the collection of antiquities was a collection of finds, which were supposedly excavated from the central course of the Pechora River, and had been brought to Estonia by Paul von Krusenstern, gifted to Karl Ernst von Baer and thereafter donated to the Provincial Museum. The collection (AM 196) includes iron and lithic points as well as human and animal-shaped plaquettes. This collection, which is rare and foreign for Estonia, has received little attention, and during the past 150 years, only a few objects have been mentioned within the framework of some broader analyses. ${ }^{1}$ However, the collection as a whole has never been introduced.

By 1873 Paul von Krusenstern had visited the Pechora River several times. A thorough descriptive book on the first expedition was pub-

DOI: http://dx.doi.org/10.12697/BJAH.2015.10.07

Translated by Juta Ristsoo.

1 Aarne Michael Tallgren, "Permian studies", Eurasia Septentrionalis Antiqua III, ed. by Uuno Taavi Sirelius, Aarne Michael Tallgren (Helsinki: K. P. Puromiehen Kirjapaino, 1928) , 63-93; 70; Eero Autio, Kotkat, hirvet, karhut: Permiläistä pronssitaidetta (Jyväskylä: Atena, 2000); Eero Autio, "The Permian Animal Style", Folklore. An electronic journal of folklore, 18/19 (2001), 18-19, 162-186; 167. 
lished in $1843 .^{2}$ However, since it does not include any references to the collection of finds in the History Museum, the collection apparently did not result from this expedition. Krusenstern's next expedition to the Pechora River took place in 1852, when he investigated the local rafting activities and the possibility of establishing a boatbuilding operation at the mouth of the Pechora River. Since the next expedition did not occur until 1874 and $1876^{3}$, it seems most probable that the collection stored at the History Museum was acquired in the course of the 1852 expedition. ${ }^{4}$ Unfortunately, as far as the authors know, the materials related to this expedition were not published and thus the exact conditions of this find are unknown. Similar finds have been made in Komi in very different contexts - in fortresses, settlements, cemeteries and also on river islands, and elsewhere. It is also possible that, despite the fact that the Revalsche Zeitung reported that the collection was excavated, actually Krusenstern and the other expedition members did not participate in the discovery, but were given the entire collection after it's discovery and it seems to include finds from different sites (see below).

These are not the only Perm animal-style examples outside of the central museum in Komi or Russia. Individual examples reached Finland already during the Late Iron Age and the early explorers of Finland brought some objects from their Russian expeditions. ${ }^{5}$ However, in Estonia only one object - a bird figurine from Nizhni Novgorod (AM 197) - represents the Perm animal-style in addition to the collection brought by Paul von Krusenstern.

2 Alexander Keyserling, Paul Theodor von Krusenstern, Wissenschaftliche beobachtungen auf einer Reise in das Petschora-Land, im Jahre 1843 (St. Petersburg: Gedruckt und zu haben bei Carl Kray, 1846). 3 Павел Иванович Крузенштерн, Путешествия П. И. Крузенштерна к Северному Уралу в годах 1874-76 для исследования водяного сообщения между притоками Печоры и Оби (С.-Петербург: Славянская печатня, 1879).

4 The 1840s saw a wider academic interest in Perm artefacts and finds, and their collection was started, see: Johannes Reinhold Aspelin, Muinaisjäännöksiä Suomen suvun asumus-aloilta (Helsinki, Pietari, Paris: G. W. Edlund, 1877); Оксана В. Игнатьева, “Деятельность А.Е. и Ф.А. Теплоуховых в отношении собирания и исследования Пермского звериного стиля”, Труды КАЭЭ ПГПУ (Пермь, 2003), 123-137; 123.

5 Autio, "The Permian Animal Style", 165 ff; Timo Salminen, "Suomen Tieteelliset voittomaat", Suomen Muinaismuistoyhdistyksen Aikakauskirja 110 (Helsinki: Suomen Muinaismuistoyhdistys, 2003). 


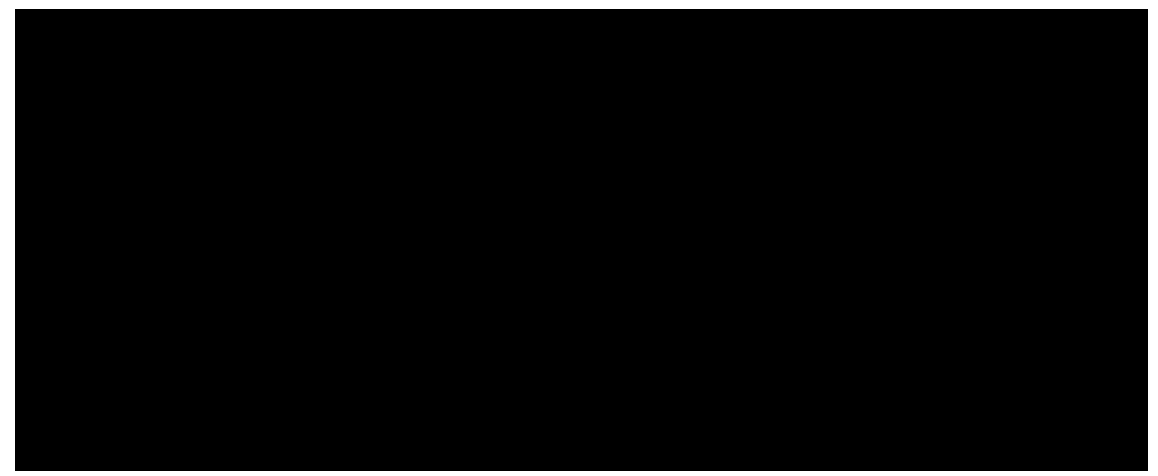

Fig.1. Lithic points. From left 4, 3, 5, 2, 1. Photo: Tõnno Jonuks.

\section{THE COLLECTION}

Twenty-six artefacts belong to the collection - ten human-head plaquettes, five different plaquettes representing birds, fish and elk, one pendant, five lithic and five iron points and a small bronze fragment of a larger object.

The earliest objects of the collection are five lithic points (Fig. 1), with short and chunky triangular form that indicates at the Eneolithic or Bronze Age. ${ }^{6}$ These are clearly the oldest objects in the collection and do not belong together with the rest of the objects.

Three clearly different types are represented among the five iron points (Fig. 2) - three flat arrowheads, which have relatively small barbs and a sharp step on the shaft form the first type $(7,9,10)$. A shallow crest is on the blade of all of them. The length of one of the point (7) - 11 cm - suggests that it could have been used even for a javelin. Another type has long barbs and a significant crest on the blade (8). Instead of a shaft, the object has a socket, but the sharp step on the socket is represented here as well. The fifth arrowhead has three blades, which all end with round holes, forming barbs (6). One of the blades is completely corroded while the others are very well preserved. This arrowhead also has a shaft. All the arrowheads can be dated to the Late Iron Age, $6^{\text {th }}$ to $12^{\text {th }}$ century AD. ${ }^{7}$

6 Владимир С. Стоколос, “Энеолит и бронзовый век”, Археология Республики Коми, ed. by Элеонора А. Савельева (Москва: ДиК, 1997), 213-313; 224.

7 Элеонора А. Савельева, Михаил В. Кленов, “Древнерусская колонизация Европейского Северо-Востока в XI-XIV н. э.”, fig 9:7, Археология Республики Коми, ed bу Элеонора А. Савельева (Москва: ДиК, 1997), 651-691. 


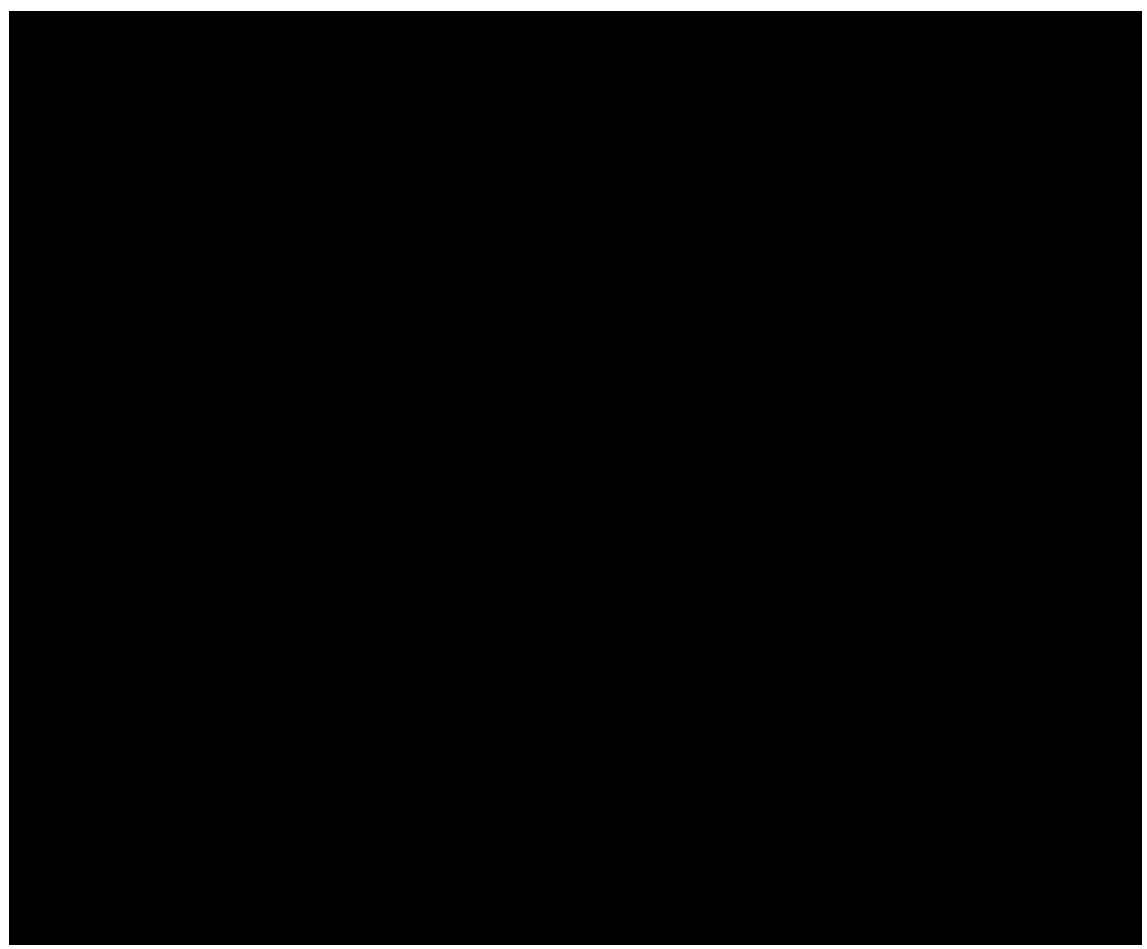

Fig. 2. Iron points. From left 7, 9, 10, 8, 6. Photo: Tõnno Jonuks.

The most outstanding objects in the collection are ten facial plaquettes. (Fig. 3) They have all been formed by making castings in single- or double-sided moulds and the detailed ornamentation (eyes, mouth, etc.) has been carved thereafter. The surface of some figurines $(11,12,13,20)$ is smoother, the remainder are uneven, thereby indicating various finishing techniques of the mould. All the figurines are 2 to $4 \mathrm{~mm}$ thick; the smaller figurines are generally thinner. The thickness of most of the figurines is uniform. Only no. 18 has an uneven thickness and measures $2 \mathrm{~mm}$ on one edge and $4 \mathrm{~mm}$ on the other. It is noteworthy that none of the figurines have eyelets that could have been used to hang the object or attach it to clothing. Also, none of the objects show signs of use or wear that would allude to them being attached to something. There are connectors in the "hair" of figurines 11, 13, 14, 15 and 20 that may have been used to hang them. At the same time, not all the figurines have, or have had, these connectors. Traces of wear are visible on the lower parts of figurines 13 and 16 and the entire face of no. 19, which were 


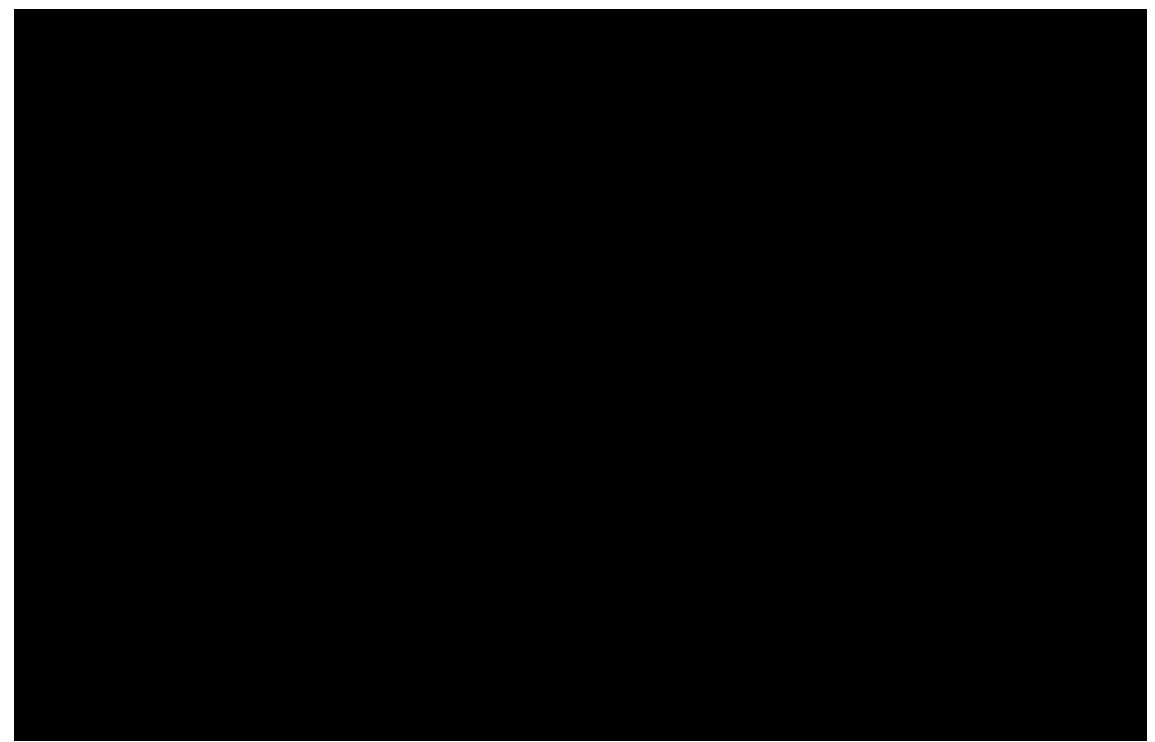

Fig. 3. Facial plaquettes. Numbers from left to right. Upper row: 11, 12, 13, 14; second row: 15, 16, 17, 18, 19, 20. Photo: Tõnno Jonuks.

apparently caused by long-term contact with a soft material. Figurine 19 also has similar traces of wear on the reverse side, while the reverse of all the other figurines have been left unfinished and covered with an uneven surface that has developed from the solidifying of the alloy. Considering the fact that the objects have no traces of fastening, some of them may have been carried or kept in bags and, after long-term contact, the soft surface of the bags may have created the traces of wear on some of the objects.

Characteristic of all the human figurines is the three branches that extend from their heads. They are mostly straight; on figurine 12 they are wavy. On figurine 15, three elk heads are depicted as the branches. Figurine 19, the ornamentation of which is harder to identify due to the wear, apparently also depicted two elk heads and the third branch between them is straight. Eero Autio has interpreted these three- and five-branched lines as hair that stood up on the shamans' heads during their ecstasy as a sign thereof. ${ }^{8}$ He also considers three branches to be an ancient Finno-Ugric trait. ${ }^{9}$

8 Eero Autio, "Horned Anthropomorphic figures in Finnish rock-paintings: shamans or something else?”, Fennoscandia archaeologica XII (1995), 13-18; 15.

9 Autio, “The Permian Animal Style”, 178. 


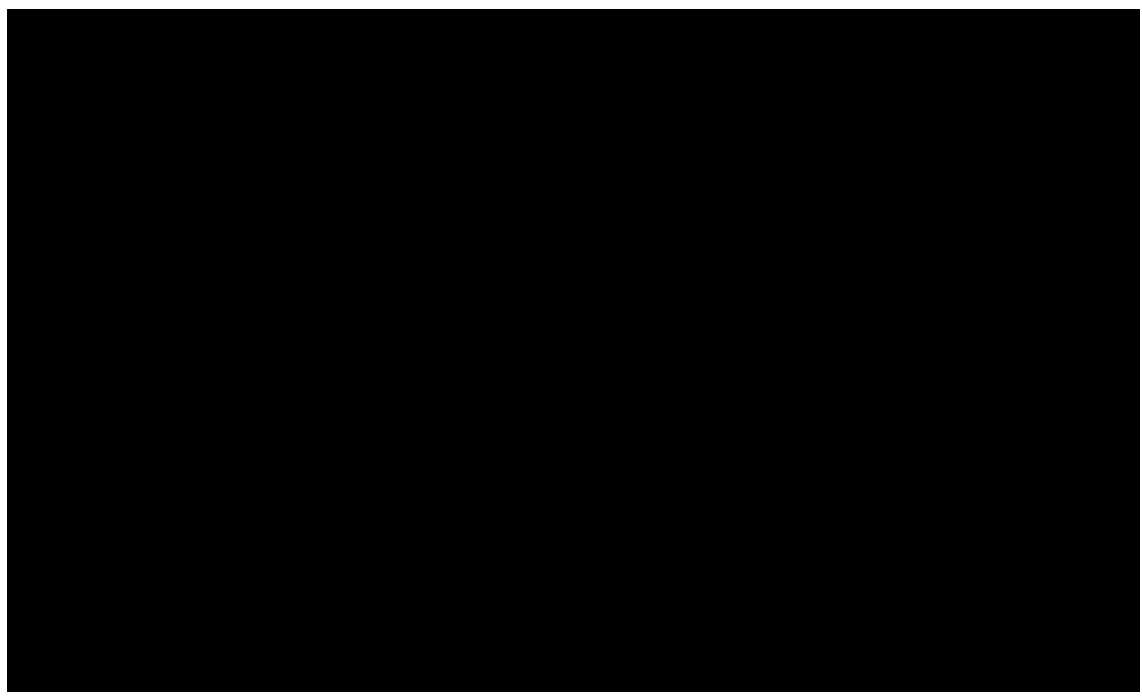

Fig. 4. Fish figurine (21) made in two-sided mould. Photo: Tõnno Jonuks.

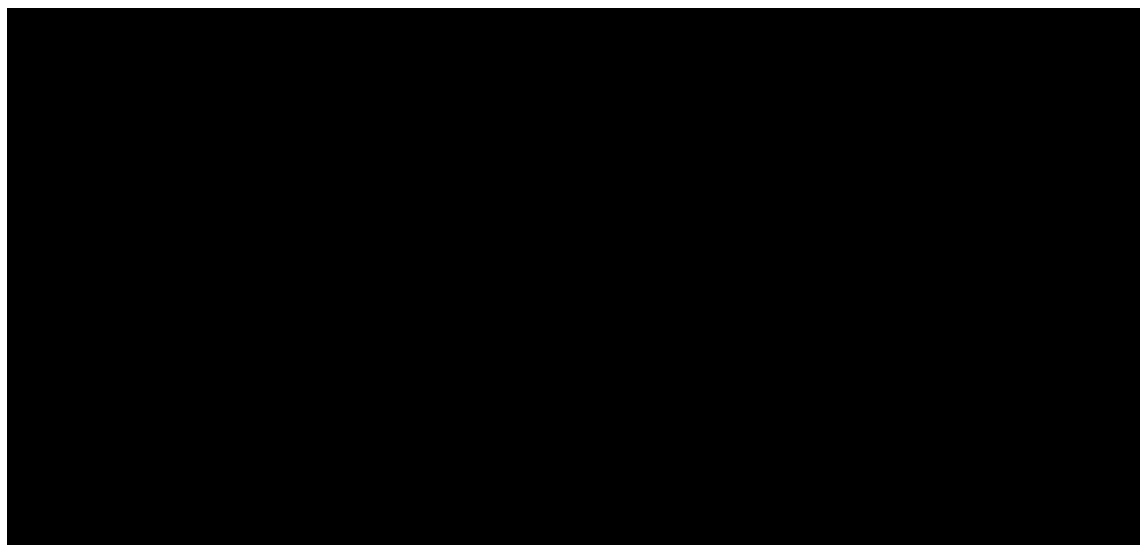

Fig. 5. Plaquette of a long-tailed bird of prey (22). Note the head of a human behind the wings. Photo: Tõnno Jonuks

All the human figurines in the collection portray only the face, although full figurines in the same style do exist. ${ }^{10}$ Of the ten human figurines, the faces of five are depicted as oval, and five as round. On

10 Seе: Александр Я. Труфанов, Жанна Н. Труфанова, “Стилистика и иконография металлопластики Няксимволя”, Няксимволь, ed by Я. А. Яковлев (Tomsk: University of Tomsk Press, 2014), 67-90. 
all of them, the facial elements include the eyes and mouth (only figurine 19 is so abrased that the mouth is not identifiable). Judging by the mouths, four figurines are sad $(14,18,17,20)$ and three are smiling $(13,15$, 16). The remaining mouths are neutral. The most unusual is the mouth of figurine 11, which is portrayed as an elk head, along with characteristically large ears and hooked nose. The eyes on all the figurines are oval. The faces on most of the figurines have no other details. The nose has been depicted on figurines $11,12,15$, and 16; the eyebrows on figurines 11, 12 and 16, and beards on figurines 11 and 12. The last two are the mostly detailed and finely finished of the figurines.

The rest of the plaquettes represent single subjects:

21 - a fish made in a double-sided mould; length $8.5 \mathrm{~cm}$, height 4.3 $\mathrm{cm}$, with two similar sides (Fig. 4). The scales, spine and tail rays, eyes and mouth are depicted. There is a 1-cm-long casting channel with a square cross section in the lower part of the fish. Based on its form, this figurine is clearly different and apparently represents another discovery site than the remaining figurines;

22 - a 10.3-cm-long figurine of a long-tailed bird made in a single-sided mould (Fig. 5). Based on the hooked nose, this is some kind of bird of prey, possibly an eagle. The wing and tail feathers are indicated by wide veins and the bird's clinched talons are also depicted. The extension behind the wing is noteworthy. Its tip is conical and there is a circle in the centre, which apparently depicts an eye. A person seems to be flying on the bird's back, but the details are unclear. Based on the person flying on the bird's back, some kind of mythological scene is apparently being depicted;

23 - an 11.6-cm-long composition with an animal or bird head, with seven human figurines on the back, was made in a single-side mould. The human figurines have long loose hair, eyes and open mouths. Of the figurines, the first is noteworthy as the vein between the figure and animal head resembles to a hand, thus leaving an impression as a human holding the animal's neck. There are three U-shaped marks on the lower portion of the composition, which coincide with the last three human figurines, and five triangles.

Eero Autio has interpreted the object as an elk-headed boat, referring to similar rock carvings. ${ }^{11}$ In this case, the row of triangles on the lower

11 Autio, "The Permian Animal Style", 167. 


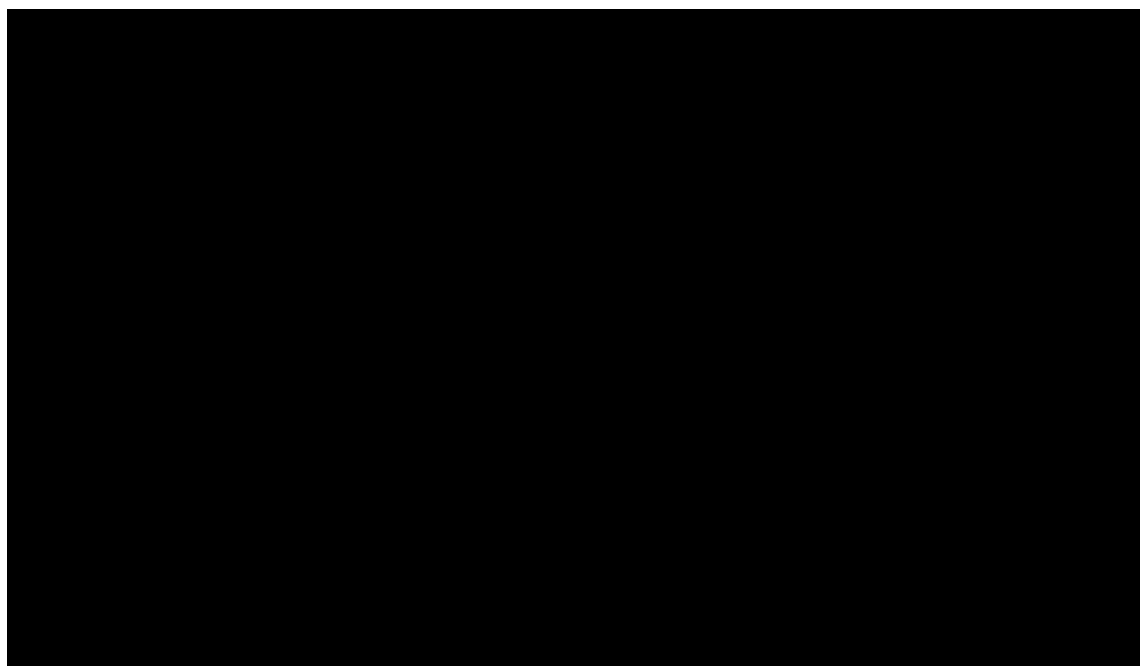

Fig. 6. Seven humans flying an eagle (23). Photo: Tõnno Jonuks.

edge of the object could be considered to be waves, etc. Based on some details, this is not an elk head but rather an eagle head, whose beak is open slightly and who is carrying a stone or something similar in its beak. The elk head interpretation suits the "horns" or "ears" behind the eyes, but the shape of the nose, and the nostril in the rear part of the nose are more reminiscent of an eagle's beak. If this is a bird's head, the figurine represents an eagle flying with several people, similarly to the previous figurine. The first human figurine, which seems to be holding onto the eagle's neck its hands, would also be well suited to this interpretation. It is more difficult to find an interpretation for the U's and triangles on the lower edge of the object. Since the U's coincide with the last three human figurines, they apparently depict the bodies of the figurines and the triangles could be viewed as the marking on the eagle's wing feathers? The human figurines flying on the eagle's back are looking in the same direction and based on their open mouths, perhaps singing. Such a composition apparently again depicts a mythological narrative. However, such an interpretation is unavoidably just a speculation and something more detailed could only be surmised if we knew the story that this figurine depicts; 


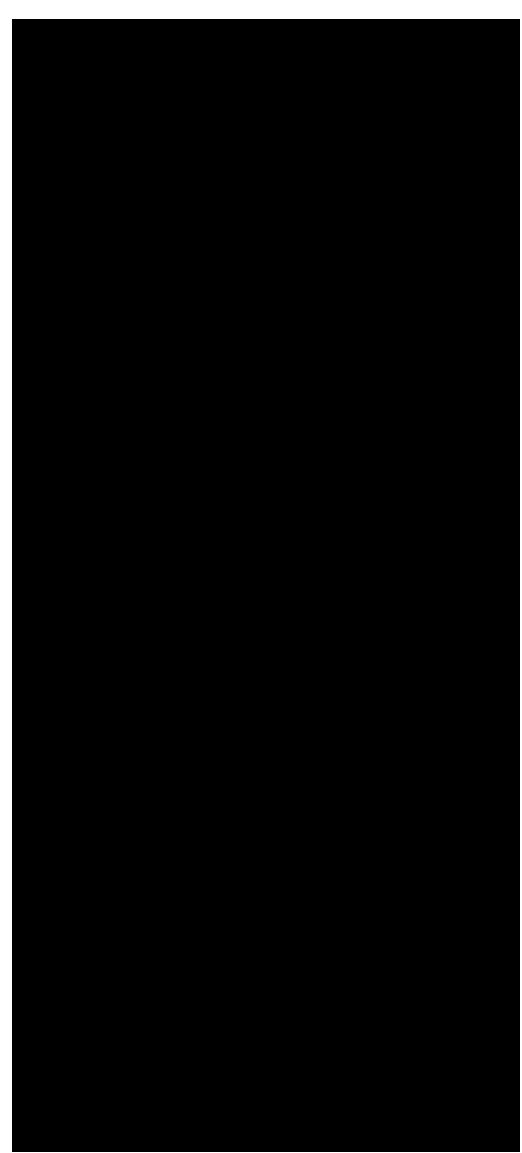

Fig. 7. A human-elk sulde (24). Photo: Tõnno Jonuks.
24 - an 8.5-cm-long "human-elk" sulde $^{12}$ that was cast in a double-sided mould (Fig. 7). Two discernible legs are depicted; the hands are represented in a stylised way, and an elk head with its snout pointed upward is depicted atop the human body. A large eye, hooked nose and halfopened mouth as well as two ears on the back of the head are clearly represented. Considerably more stylised is the image on the reverse of the figurine, where the legs are indicated by two veins cut into the form, and the elk head is represented by a few veins and depressions. The figurine depicts a classical human-elk, whose snout, which is pointed to the sky, has been associated with the arch of the heavens or heavenly creatures ${ }^{13}$; 25 - a fish, $4.7 \mathrm{~cm}$ long and $1.6 \mathrm{~cm}$ wide, cast in a single-sided mould (Fig. 8). A relatively short and thick body is depicted; spruce twig motif in the central section apparently represents the fish scales. In the top view, we see two eyes and sharptipped nose. Veins are carved in the four corners of the figurine's body, which, based on an alternative interpretation, could also allude to another animal, for example, a beaver. At the same time, beavers are usually depicted as blunt-nosed ${ }^{14}$, and this figurine lacks the beaver's typical tail. Other examples exist of similar fish-shaped figurines with sharp nos-

12 Ibidem, 162.

13 Лариса И. Липина, Семантика бронзовых зооморфных украшений Прикамского костюма (сер. I тыс. До н.э. - нач. II тыс. Н.э.) (Ижевск: Unpublished doctoral thesis, 2006), 101 ff. Available at http://www.perm-animal-style.ru/wp-content/uploads/2011/04/Lipina.pdf (retrieved on 10.12.2015). 14 See: Труфанов, Труфанова, “Стилистика и иконография металлопластики Няксимволя”, $142 \mathrm{ff}$. 


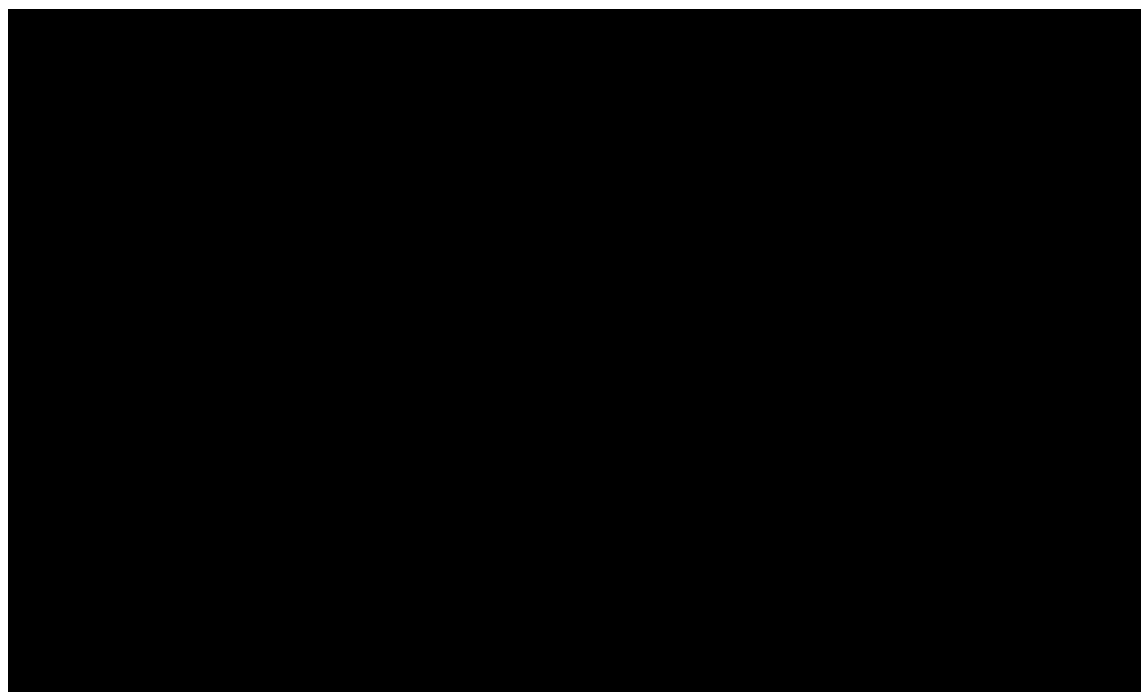

Fig. 8. A fish plaquette (25). Photo: Tõnno Jonuks.

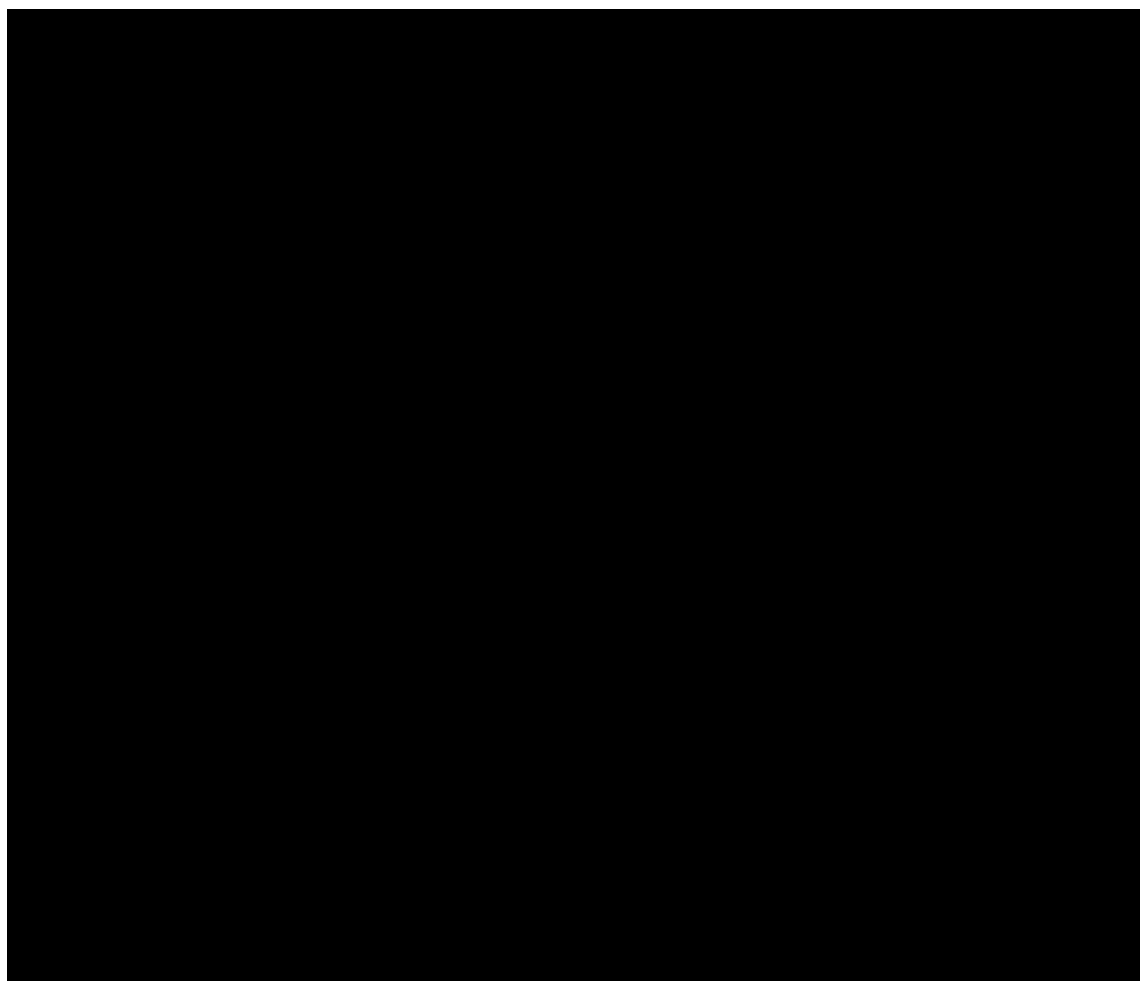

Fig. 9. A pendant with the depiction of a snake (26). Photo: Tõnno Jonuks. 
es as characteristic traits. ${ }^{15}$ The angle that reveals the fish's sharp nose and two eyes indicates that the fish is swimming and we are looking at it from above through the water. The latter indicates that the plaquette depicts a living creature and the figurine symbolised communication with the fish in the river;

26 - the only pendant in the collection is cast in a single-sided mould (Fig. 9). This is a round object $3.1 \mathrm{~cm}$ in diameter with an eyelet for hanging. A large-eyed snake is curled in the centre of the pendant in three circles. The mouth seems to be opened but it could also be just damage suffered during casting;

27 -a bronze button with an eyelet, hollow and with an extension (Fig. 10). This is clearly a fragment, which does not come from any of the objects in the collection. It is possible that it is the fragment of a chain holder ${ }^{16}$;

AM 197 - the figurine also represents the Perm animal style, but it comes from Nizhni Novgorod (Fig. 11). The figurine is cast in a double-sided mould, but intended to be viewed from only one side. The figurine depicts a very stylized bird with outspread wings and a massive beak. Three horizontal lines are depicted on the expanding body below.

\section{METAL ANALYSES}

Perm animal-style plaquettes have usually been described as being made of bronze. The colour of the figurines of this collection, however, was too grey for being identified as "bronze" and green bronze patina was also not present on any of the objects. So a question about the material of the plaquettes arose. An element analysis was carried out on metal figurines with a handheld X-ray fluorescence (XRF) spectrometer Bruker Tracer III-SD. ${ }^{17}$ Due to the rarity of the figurines, no grinding of the corrosion layer was done on the measured surfaces. Due to the latter, the

15 See: Tallgren, "Permian studies", $76 \mathrm{ff}$.

16 Е.g. Александр Спицынь, “Древности Камской чуди по коллекции Теплоуховыхь”, Материалы по археологии России Но 26 (С-Петербургь: Типография В. Безобразова и Ко, 1902), Tab XIV, 8.

17 All the copper alloys were measured with settings of $40 \mathrm{kV}, 10.7 \mu \mathrm{A}$, and metal alloys filter (12 mil Al $+1 \mathrm{mil} \mathrm{Ti}$ ). The measuring time was $60 \mathrm{~s}$ (AM 196: $11-15)$ and $300 \mathrm{~s}$ (AM 196: 16 - 27). The measurements were quantified using the native Bruker copper alloys calibration CU1 and in two cases (AM 196: 17, 21) with a manufacturer provided calibration CU3. 


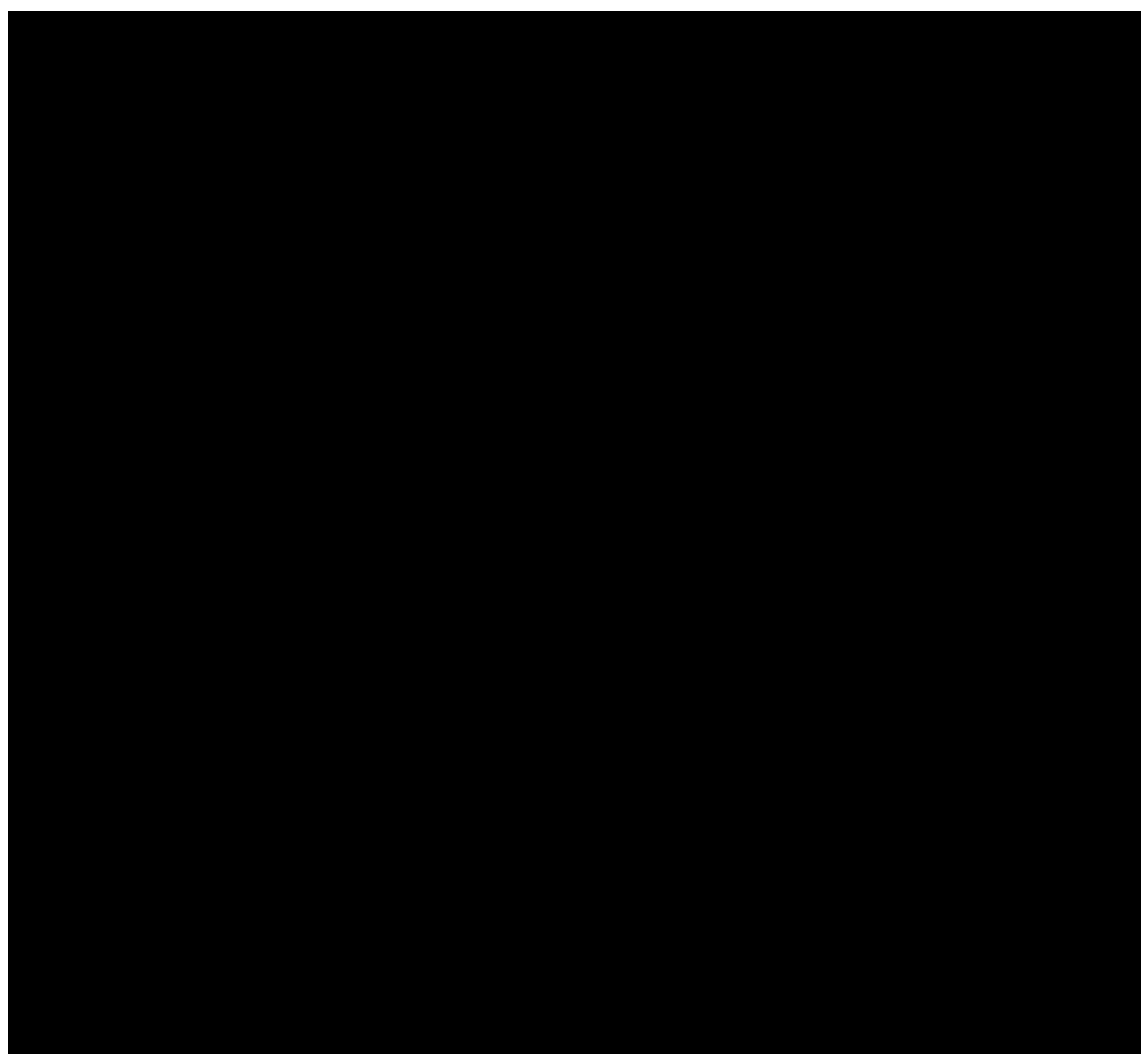

Fig. 10. A fragment of a possible chain holder (27). Photo: James Miles (OÜ Arheovisioon).

measurements should be considered semi-quantitative as they characterise the content of the corrosion layer and not the original artefact metal.

The analysis of the alloy corrosion revealed very high levels of tin (Sn) in the copper $(\mathrm{Cu})$ alloy for all the artefacts except the fish figurine (21), which is leaded $(\mathrm{Pb})$ bronze (table 1 ). Based on the surface analysis the large variation of the tin, copper, lead and iron (Fe) content is attributed to the different corrosion products.

Based on the trace elements of arsenic (As), mercury ( $\mathrm{Hg})$, silver (Ag) and gold $(\mathrm{Au})$, some of the figurines might have been made from a slightly different raw material (table 1). The most common combination was the occurrence of arsenic, mercury and silver. One of the figurines lacked arsenic (26), one lacked silver (20), and one lacked mercury and silver (14). Two figurines contained all four trace elements $(19,25)$. The 


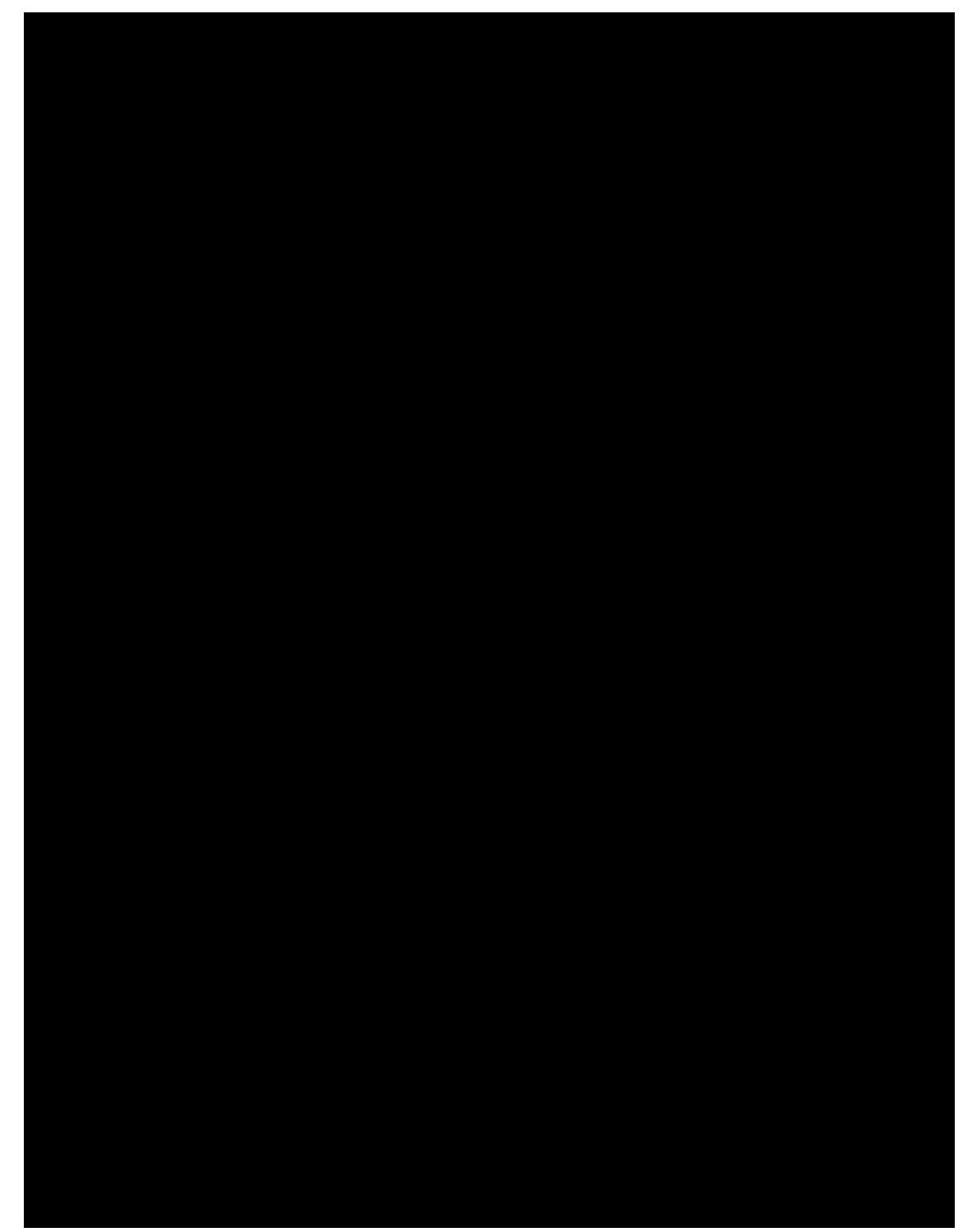

Fig. 11. A bird figurine from Nizhni Novgorod (AM 197). Photo: Tõnno Jonuks.

leaded bronze figurine of a fish, mentioned above (21) was the only object that was missing mercury as a trace element.

In conclusion, it should first be noted that all the figurines (except no 21) were made of a tin-copper alloy with a considerably high tin content. 
Bronze is usually considered an alloy where tin is present in the copper matrix, but most of the compositions measured from the surface of the figurines display an alloy where the copper content is smaller than tin's. Without grinding the surfaces it is impossible to determine the exact composition of the figurines - therefore it is difficult to judge how much control the manufacturer had over the alloy composition while casting the objects. However, it is possible, that the exceptionally high tin content was intentional in order to achieve a certain colour (similar to silver?) for the figurine or lower the melting temperature of the bronze alloy.

Based on the measurement of the alloys, it can be safely stated that the fish figurine (no. 21) with its considerably different alloy, but also with different stylistic features, represents a tradition that differs from the rest of the collection. It is difficult to prove but possible that some smaller clusters can be found also among the rest of plaquettes. These clusters could, but might not, indicate different masters or locations, but this could also depend on the raw metals that were used.

\section{FINAL DISCUSSION AND CONCLUSIONS}

The analyses described above indicate that the collection of finds brought from Komi by Paul von Krusenstern is most probably an antiquarian collection comprised of objects from various discovery sites. The oldest of these are the five lithic points, which have little relation to the remaining objects. Based on both the style and metal composition, one can be sure that the two-sided fish figurine (no 21) represents a separate story. Since Perm animal-style objects continued to be made until the $19^{\text {th }}$ century $^{18}$, this figurine may represent the later traditions of the style. The iron points can be dated back to the Late Iron Age ( $6^{\text {th }}$ to $12^{\text {th }}$ century $)^{19}$ and it is possible that they too originate from different discovery sites.

The earliest examples of facial figurines date back to the Bronze Age and the era of the Ananino culture. ${ }^{20}$ There are numerous figurines in this collection that are similar in both style and technique to ones found in the Nyaksimvol hillfort in the Sverdlovsk oblast, which have

18 Андрей М Белавин, “Об этнической приндлежности Пермского средневекого звериного стиля”, Труды КАЭЭППУ, 1-2 (2001), 14-24; 20.

19 Белавин, “Об этнической приндлежности Пермского средневекого звериного стиля”, 20.

20 Мариа С. Коренюк, “Металлические антрпоморфные изображения в раннем желесном веке Пермского прикамья”, Вестник Пермского Университета, 1 (28) (2015), 85-98. 
been dated back to a long period between the $4^{\text {th }}$ century BC and $6^{\text {th }}$ century AD. ${ }^{21}$ However, in Komi generally, the tradition of facial and zoomorphic plaquettes continued until the $12^{\text {th }}$ century AD.22 Therefore, these figurines represent a very long tradition of making human- and animal-shaped plaquettes and the execution methods and style have changed very little over time.

The strong emphasis on human heads in the collection is noteworthy. Among other things, the collection has no bear figurines, which was a very popular motif. Also elks and birds, two very dominant characters in the Perm animal-style, are represented by only a few examples. This makes it probable that Paul von Krusenstern's collection was deliberately assembled from different sites in the 1840s and 1850s, with an emphasis on the types of figurines that were popular and attractive at the time, and were looked for and collected. Therefore, the collection can be considered to be one that is based primarily on antiquarian interests and was gifted to Captain Krusenstern as the high representative of tsarist power. Naturally, the possibility that the figurines were found together cannot be excluded, especially if we consider the large number of similar plaquettes from the Nyaksimvol hillfort.

This emphasis, based on the interest of researcher or collector and the general spirit of the era, can also be followed thereafter. The first publication on the collection mentioned only the human heads $\mathrm{s}^{23}$, since this topic was the most attractive one in the late $19^{\text {th }}$ and early $20^{\text {th }}$ century. However, the animal figurines, which remained in the background, received more attention in Eero Autio's publications ${ }^{24}$, since as a researcher of rock carvings in which animal figures play an important role, he focused on the zoomorphs of the collection in his interpretations. One of the bird figurines (no. 23) was also introduced at that time, interpreted as an elk, based on the elk-headed boats that occur in rock carvings. ${ }^{25}$ Although the author was well aware of the differences in geography and dating, the research story was affected by what the focus of attention was, how this was done, and which examples were connected to each other.

21 Труфанов, Труфанова, “Стилистика и иконография металлопластики Няксимволя”.

22 Белавин, “Об этнической приндлежности Пермского средневекого звериного стиля”.

23 Tallgren, "Permian studies”, 70-71.

24 Autio, "Horned Anthropomorphic figures in Finnish rock-paintings: shamans or something else?”; Autio, "The Permian Animal Style".

25 Autio, "The Permian Animal Style", 167-168. 
Similar Perm animal-style plaquettes have mostly been interpreted according to three traditions that are intertwined and had gotten their beginning in the early $19^{\text {th }}$ century: the figurines depict shamans and their helping spirits ${ }^{26}$; they depict mythological beings and the scenes related to them ${ }^{27}$; and third, that the figures are related to totemic images. ${ }^{28}$

Clearly the various interpretive methods can be entwined and some of the figurines may depict the shamans' helping spirits; others myths of the same religious system. Yekaterina Prokofyeva describes the costume of a female Enets shaman and the iron pendants on the breastplate or apron that depict people flying on a bird's back are very similar to the figurines in this collection. According to Prokofyeva, the figurines depict the shaman's helping spirits, the "sky people". ${ }^{29}$ Since all the spirits had their own role, and there were narratives related to their birth and origins, the figurines often depict a mythological story. A good example of this is provided by the costume of Tubyaku Kosterkin, a Nganasan shaman. ${ }^{30}$ Thus, object no. 22 in this collection with a man on an eagle's back, may actually depict the shaman's soul flying on an eagle-shaped helping spirit. No. 23 apparently depicts a more complicated narrative with an eagle, which is carrying something in its beak or has stolen it and is also carrying seven people or souls on its back.

The elk phenomenon definitely relates best to totemism, or the idea of mythical forebears. At this point, it is interesting to note that the elk was an important animal in Stone Age ideologies throughout Eurasia, but during the Iron Age, its role became limited to the Perm areas, where it also became one of the most important iconographic characters. ${ }^{31}$ Focusing on one animal species in such a restricted area is also the best source for the totemic interpretation, especially if we recall the human-elk in this collection, which seems to connect the animal central to the ideology with a human (forebear?). Larisa Lipina adds more

26 Kustaa Fredrik Karjalainen, Jugralaisten uskonto (Porvoo: WSOY, 1918).

27 For references, see: Игнатьева, “Деятельность А.Е. и Ф.А. Теплоуховых в отношении собирания и исследования Пермского звериного стиля”, 134.

28 For references, see: Autio, “The Permian Animal Style”; Липина, Семантика бронзовых зооморфных украшений Прикамского костюма (сер. I тыс. До н.э. - нач. II тыс. Н.э.).

29 Yekaterina Prokofyeva, "The costume of an Enets shaman", Studies in Siberian Shamanism, ed by Henry N. Michael (Toronto: University of Toronto Press, 1963), 124-156; 139.

30 Aado Lintrop, "The Incantations of Tubyaku Kosterkin", Folklore. An Electronic Journal of Folklore, 2 (1996). See: https://www.folklore.ee/folklore/vol2/tubinc.htm (retrieved on 10.12.2015).

31 Липина, Семантика бронзовых зооморфных украшений Прикамского костюма (сер. I тыс. До н.э. - нач. II mыс. Н.э.), 98. 
mythological aspects to the totemic interpretation - the elk as the symbol of the sun; the opposition between the elk and the bear or the hunting situation, and the elk-bird connection. And the symbolism that occurs most clearly in the iconography of the animal connects the elk with the symbol of Earth in a three-part worldview. ${ }^{32}$

It is probably very difficult, if not impossible, to discern any definite and specific meanings in these plaquettes. Depending on the era and even more on the personal vernacular usage, each symbol and figurine may have had different meanings. Thus, the eagle that is transporting people (or their souls?) may be a shaman's helping spirit, who simultaneously embodies an ancestor and the stone or other object in its beak may refer to a myth associated with it.

Thus, in the case of this collection, it is difficult to determine a definite date or interpretation. It seems probable that the entire collection was assembled based on antiquarian interests and embodies the initial spirit related to research of the history of Perm in the mid-19th century. Apparently an attractive collection of objects that were attracting interest at that time was assembled for Captain Krusenstern, which included lithic and iron points and human/animal-shaped plaquettes made of copper-tin alloy.

The authors of this paper are grateful to PhD Erki Tammiksaar, Prof Aivar Kriiska, archaeologist Irina Timusheva and Kaspar Säre for their help and advice. This study was supported by institutional research funding IUT22-5 from the Estonian Ministry of Education and Research, the European Union through the European Regional Development Fund (Centre of Excellence in Cultural Theory) and by the basic financing program for national fields PFLAJ 909905.

32 Ibidem, 105. 


\begin{tabular}{|c|c|c|c|c|c|c|c|c|}
\hline Figurine & Cu & Sn & Pb & Fe & As & Hg & Ag & Au \\
\hline AM 196:11 & $46.5 \%$ & $46.6 \%$ & $5.0 \%$ & $1.7 \%$ & + & + & + & - \\
\hline AM 196:12 & $28.9 \%$ & $68.2 \%$ & $1.6 \%$ & $0.2 \%$ & + & + & + & - \\
\hline AM 196:13 & $27.1 \%$ & $70.5 \%$ & $1.3 \%$ & $0.2 \%$ & + & + & + & - \\
\hline AM 196:14 & $38.8 \%$ & $59.8 \%$ & $0.5 \%$ & $0.2 \%$ & + & - & - & - \\
\hline AM 196:15 & $24.7 \%$ & $68.3 \%$ & $0.9 \%$ & $5.9 \%$ & + & + & + & - \\
\hline AM 196:16 & $46.6 \%$ & $49.4 \%$ & $1.9 \%$ & $1.8 \%$ & + & + & + & - \\
\hline AM 196:17 & $36.5 \%$ & $59.8 \%$ & $3.0 \%$ & $0.5 \%$ & + & + & + & - \\
\hline AM 196:18 & $27.8 \%$ & $64.7 \%$ & $4.7 \%$ & $1.3 \%$ & + & + & + & - \\
\hline AM 196:19 & $32.4 \%$ & $62.9 \%$ & $3.2 \%$ & $0.2 \%$ & + & + & + & + \\
\hline AM 196:20 & $46.1 \%$ & $50.8 \%$ & $1.8 \%$ & $0.4 \%$ & + & + & - & - \\
\hline AM 196:21 & $69.6 \%$ & $1.9 \%$ & $27.8 \%$ & $0.4 \%$ & + & - & + & - \\
\hline AM 196:22 & $39.8 \%$ & $54.4 \%$ & $3.4 \%$ & $1.1 \%$ & + & + & + & - \\
\hline AM 196:23 & $32.1 \%$ & $63.6 \%$ & $2.6 \%$ & $0.6 \%$ & + & + & + & - \\
\hline AM 196:24 & $34.2 \%$ & $61.2 \%$ & $2.3 \%$ & $0.7 \%$ & + & + & + & - \\
\hline AM 196:25 & $29.5 \%$ & $66.3 \%$ & $2.0 \%$ & $0.8 \%$ & + & + & + & + \\
\hline AM 196:26 & $29.2 \%$ & $67.5 \%$ & $2.1 \%$ & $0.2 \%$ & - & + & + & - \\
\hline AM 196:27 & $20.8 \%$ & $70.4 \%$ & $3.8 \%$ & $3.6 \%$ & + & + & + & - \\
\hline
\end{tabular}

Table 1. Chemical composition of the figurines $(\mathrm{Cu}, \mathrm{Sn}, \mathrm{Pb}, \mathrm{Fe})$ and the occurrence of trace elements ( $\mathrm{As}, \mathrm{Hg}, \mathrm{Ag}$, $\mathrm{Au}$ ). Colours mark the composition ranges for $20 \%, 40 \%$ and $60 \%$. 
Tõnno Jonuks, Ragnar Saage: An Antiquarian Gift - A Collection of Perm Animal-Style Plaquettes in the Estonian History Museum

KeYWords: Perm ANimal STYLE; PORTABle-XRF; ANTIQUARIANism; HUMAN FIGURINES; ZOOMORPHIC FIGURINES

CV:

Tõnno Jonuks (PhD) is a senior research fellow at the Estonian Literary Museum, Department of Folklore. His main interest is Estonian religion in different periods. He has published on various subjects from the Mesolithic to Modern Age, but also about the theory and historiography of the archaeology of religion. In addition to sacred sites and landscapes, his recent interest is material culture studies, especially figurines and pendants.

Ragnar Saage (MA) is a doctoral student at the Tartu University. For his MA thesis, he studied the medieval and early modern smithy site of Käku on the island of Saaremaa. Currently, he is mainly working with smithy and casting sites from Iron Age, Medieval and Early Modern Estonia using elemental and metallographic analysis and 3D modelling. 
